\title{
風荷重を想定した鉛プラグ入り LONG-DURATION LOADING TEST 積層ゴムの長時間加振実験 ON LEAD RUBBER BEARINGS CONSIDERING WIND LOAD
}

\section{高岡栄治—— \\ 近藤明洋 — $* 3$ \\ 片村立太——5 \\ 大熊武司 — $*$ * 7 \\ キーワード : \\ 免震構造, 鉛プラグ入り積層ゴム，風応答，加振実験， \\ オンライン実験

竹中康雄—*2
引田真規子— $* 4$
飯場正紀— 66

Keywords:

Base-isolated structure, Lead rubber bearing, Wind response, Loading test, Online test

$\begin{array}{ll}\text { Eiji TAKAOKA } & * 1 \\ \text { Akihiro KONDO- } & * 3 \\ \text { Ryuta KATAMURA } & * 5 \\ \text { Takeshi OKUMA- } & * 7\end{array}$

To grasp the effects of creep characteristics and rising temperatures on lead rubber bearings under wind load, long-duration cyclic loading tests and real-time online tests were conducted. From the loading tests, the lateral restoring characteristics of the lead rubber bearings in the small deformation range considering the creep characteristics were obtained. Analytical results using a simplified estimation method considering the small deformation characteristics of lead rubber bearings agreed well with the test results. From the online tests, the response properties of a base-isolated building under wind load were experimentally verified, and the validity of the modeling approach for lead rubber bearings and the wind response analysis method were confirmed.

\section{1.はじめに}

近年、免震構造が高層建物に適用されるようになり、外力として 風外力が無視できない存在になってきている。風外力は地震外力と 異なり継続時間が長いのが特徴であり、さらに、建物が風向方向の 風外力を受ける場合、平均成分と呼ばれる静的な成分と変動成分と 呼ばれる動的な成分を組み合わせた外力が建物に作用することによ り、免震部材に地震時とは異なる挙動が生じる可能性がある。具体 的には、風向方向の風外力に含まれる平均成分により生じるクリー プ変形、長時間の繰り返し変形に伴う疲労、免震部材の温度上昇に 伴う力学特性の変化などである。

以上の背景に対して、鉛プラグ入り積層ゴム (LRB) については、 風荷重を想定した長時間加振実験が実施されており、最終的な水平 変形が風荷重の平均成分とゴムのみの水平剛性による荷重が釣り合 う変形に収束すること、LRB の降伏荷重以下の水平荷重の範囲にお いては、LRB 内部の温度はほとんど上昇しないことなどが確認され

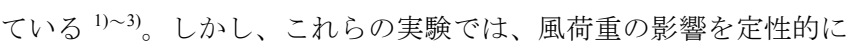
捉えることを目的としており、実験の入力条件等の現行免震設計に 対する位置づけは不明確である。これに対して、免震部材の通常の 設計範囲、寸なわち強風によって降伏が生じない、あるいは降伏繰 り返し数が限定的であるような場合を想定し、免震部材の挙動や安 全性を確認するための試験方法が提案されている ${ }^{4)}$ ここでは、実 際の長時間にわたる非定常な風荷重を、等価な正弦波荷重に置換し て載荷する方法が示されている。しかし、これらの試験方法は、免 震建物の風応答解析の結果に基づき評価された手法であり、その妥 当性について実験的な検証は行われていない。
上記課題を踏まえて、本論では、LRB を対象として、通常の設計 範囲を想定した風荷重下におけるクリープ特性や温度上昇の影響等 を把握することを目的とし、文献 4)で提示された試験方法に基づく 長時間加振実験を実施するとともに、実験結果の数值解析を行なっ た。また、風外力を受ける免震建物の挙動については、これまで数 值計算による検討のみが行われ、観測データとの比較による検証は 行われていない。そこで、風外力に対する建物の応答特性および免 震部材のモデル化と応答解析法の妥当性を検証するため、コンピュ 一タ内における風応答解析と積層ゴムの加力実験を並行して行ない 解析の復元力に実験から得られた值を直接用いるオンライン応答実 験をリアルタイムで実施した。

\section{2. 実験方法}

\section{1 試験体}

試験体は直径 $500 \mathrm{~mm}$ の LRB である。原型として直径 $1000 \mathrm{~mm}$ を 想定し、これを $1 / 2$ に縮小した縮小試験体であり、試験体数は 2 体 （LRB1 試験体、LRB2 試験体）である。試験体の形状と寸法を表 1 および図 1 に示す。設計值としてのゴムのせん断弾性係数 $G$ は $0.4 \mathrm{MPa}$ 、鉛の降伏せん断応力度 $\tau_{P B}$ は $8.33 \mathrm{MPa}$ である。LRB の降伏 荷重 $Q_{y}\left(=\pi D_{P}^{2} / 4 \times \tau_{P B}\right)$ は $65.4 \mathrm{kN}$ である。

\section{2 実験ヶース}

実験は、正弦波加振実験、風応答波加振実験、オンライン応答実 験の 3 種類に分けて実施した。各実験における入力波については、 LRB で支持された免震建物モデル（地上 47 階 RC 造、高さ $160 \mathrm{~m}$ 、 以下モデル免震建物）を対象とした風応答解析 ${ }^{4) \sim 6)}$ の結果に基づき

\footnotetext{
鹿島建築管理本部 課長・博士 (工学)

（柇 107-8348 東京都港区赤坂 6-5-11)

鹿島建築設計本部 シニアマネージャー・工修

鹿島建築設計本部 チーフエンジニア・工修

鹿島技術研究所 研究員 · 工修

鹿島技術研究所 主任研究員

建築研究所構造研究グループ グループ長・博士（工学）

神奈川大学 名誉教授・工博
}

\footnotetext{
Manager, Building Construction Management Division, Kajima Corporation, Dr Eng.

Senior Manager, Architectural Design Division, Kajima Corporation, M. Eng.

Chief Engineer, Architectural Design Division, Kajima Corporation, M. Eng.

Research Engineer, Kajima Technical Research Institute, Kajima Corporation, M. Eng.

5 Senior Research Engineer, Kajima Technical Research Institute, Kajima Corporation

6 Director, Dept. of Structural Engineering, Building Research Institute, Dr. Eng. Prof. Emeritus, Kanagawa Univ., Dr. Eng.
} 
設定した。モデル免震建物は総重量 $652200 \mathrm{kN}$ 、基礎固定時固有周期 3.13 秒で、免震特性としては、前述の原型 LRB により平均面圧 $14.7 \mathrm{MPa}$ で支持させているものとし、ゴム剛性のみによる免震周期 5.5 秒、免震層降伏せん断力係数 0.024 である。風外力については、 東京地方（地表面粗度区分 II）を想定し、実観測記録と風洞実験結 果を用いて 4.5 時間の時刻歴波形を風向方向および風向直交方向の 2 ケースについて作成した。解析では、LRBのモデルとして小振幅 特性を考慮した修正 HD モデル 7)を採用するとともに、クリープ変 形の影響を考慮して、平均成分が鉛に抵抗しないという仮定の下に 風外力時刻歴波形を平均成分と変動成分とに分けてそれぞれの応答 評価を行なった上で、両者を合算する簡易評価法を用いた ${ }^{3)}$ 。

(1)正弦波加振実験

前述の風応答解析の結果に従い、強風によって LRB が降伏しない 通常の設計範囲を想定した入力波を設定した。正弦波加振実験の実 験ケースを表 2 に示す。入力波は一定荷重 $Q$ と正弦波荷重 $\Delta Q \cdot \sin 2 \pi t / T$ ( $T$ : 加振周期) の和による荷重波形 $Q+\Delta Q \cdot \sin 2 \pi t / T$ で、 $Q$ と $\Delta Q$ の組み合わせとしては、LRB の降伏荷重 $Q_{y}$ を考慮し た 5 ケースを設定した。 $\alpha$ については、風外力変動成分に対する免 震層せん断力の時刻歴応答において、RMS 值の最大值に対する比率 が 0.40 以下であったことに基づき 0.4 とした。加振時間については、 全風速域 4.5 時間の免震層消費エネルギーが最大風速域 50 分間の值 の 2 倍程度であったことを参考にして 2 時間とした。加振周期 $T$ は 3 秒とした。残留変形に関するデータを取得するため、加振終了後 も 2 時間の計測を行なった。その際の荷重条件は、荷重をゼロとす るケース（荷重ゼロ）を基本とするが、強風が徐々に小さくなるこ とを想定し平均成分と変動成分が 2 時間後にゼロとなるように漸減 させるケース（漸減加振）も実施した。なお、2 時間後に残留変形 が収束していないと判断された場合、引き続き計測を行なった。

(2)風応答波加振実験

前述の風応答解析から得られた継続時間 4.5 時間の免震層水平荷 重の時刻歴波形を、試験体 1 台分に換算して入力した。実験ケース は風向方向および風向直交方向の 2 ケースである。表 3 に風応答波 加振実験の実験ケースを、図 2 に入力波形を示す。

(3)オンライン応答実験

オンライン応答実験とは、時刻歴応答解析と部材加力実験を並行 して行ない、部材の復元力特性を取り込みながら解析を進めていく 実験手法である。ここでは、免震建物の上部構造を解析対象とし、 積層ゴム部分の復元力特性を実験によって求めた。上部構造のモデ ルは、モデル免震建物のそれを、外力分布を含めて縮約した 11 質点 系等価せん断型モデルとした。表 4 に上部構造モデルの諸元を示す。 上部構造は弾性とし、減衰は上部構造基礎固定時の 1 次周期 3.13 秒 に対して $1.5 \%$ の内部粘性減衰を考慮した。数值積分法としては Newmark $\beta$ 法（ $\beta=0 ）$ を適用し、積分時間刻みを 0.005 秒とした。 風荷重によるクリープ現象も対象とするため、実験はリアルタイム で実施した。実験ケースは風応答波加振と同様、風向方向および風 向直交方向の 2 ケースである（表 3）。

\section{3 加振方法と計測方法}

図 3 に加力装置を示す。1000kN アクチュエータ 2 台によって鉛直 荷重を、500kN アクチュエータ（最大速度 $500 \mathrm{~mm} / \mathrm{s}$ 、ストローク $\pm 300 \mathrm{~mm})$ によって水平荷重を試験体に与えた。試験体と加力装置

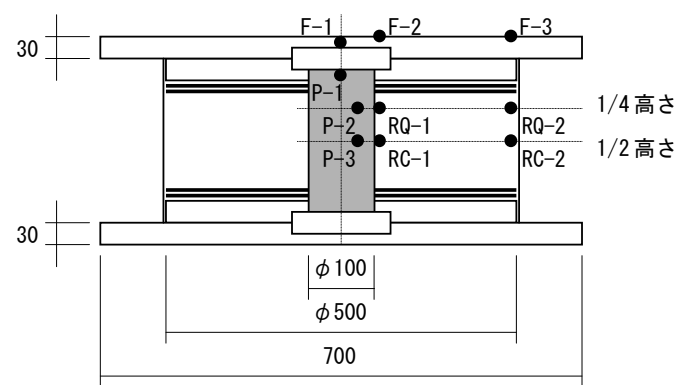

図 1 試験体と温度計測点

表 1 試験体形状

\begin{tabular}{|c|c|c|c|}
\hline & & 原型 & 試験体 \\
\hline 外径 $D$ & $(\mathrm{~mm})$ & 1000 & 500 \\
\hline 鋁径 $D_{P}$ & $(\mathrm{~mm})$ & 200 & 100 \\
\hline ت゙ム一層厚 & $(\mathrm{mm})$ & 6.0 & 3.0 \\
\hline ヨ゙ム層数 & & 33 & 33 \\
\hline ت゙ム総厚 & $(\mathrm{mm})$ & 198 & 99 \\
\hline 内部鋼板厚 & $(\mathrm{mm})$ & 4.4 & 2.2 \\
\hline 1 次形状係数 & $\mathrm{S}_{1}$ & 41.7 & 41.7 \\
\hline 2 次形状係数 & $\mathrm{S}_{2}$ & 5.1 & 5.1 \\
\hline
\end{tabular}

表 2 正弦波加振実験の実験ケース $(\alpha=0.4)$

\begin{tabular}{|c|c|c|c|c|}
\hline \multirow{2}{*}{ ケース名 } & \multicolumn{2}{|c|}{ 荷重 } & \multirow{2}{*}{ 加振時間 $(\mathrm{h})$} & \multirow{2}{*}{ 加振終了後 } \\
\cline { 2 - 4 } & $Q$ & $\Delta Q$ & \\
\hline $\mathrm{L}-1$ & $Q_{y} / 5$ & $\alpha \cdot Q_{y} / 5$ & 2 & 荷重ゼロ \\
\hline $\mathrm{L}-2$ & $Q_{y} / 2$ & $\alpha \cdot Q_{y} / 2$ & 2 & 荷重ゼロ \\
\hline $\mathrm{L}-3$ & $Q_{y}$ & $\alpha \cdot Q_{y}$ & 2 & 荷重ゼロ \\
\hline $\mathrm{L}-4$ & $Q_{y}$ & $\alpha \cdot Q_{v}$ & 2 & 漸隇加振 \\
\hline $\mathrm{L}-5$ & 0 & $1.5 \cdot \alpha \cdot Q_{y}$ & 2 & 荷重ゼロ \\
\hline
\end{tabular}

表 3 風応答波加振実験・オンライン応答実験の実験ケース

\begin{tabular}{|c|c|c|c|}
\hline ケース名 & 実験種類 & 入力波形 & 加振時間 $(\mathrm{h})$ \\
\hline L-6 & 風応答波加振 & 風向方向応答 & 4.5 \\
\hline L-7 & 風応答波加振 & 風向直交方向応答 & 4.5 \\
\hline L-8 & オンライン忘答 & 風向方向応答 & 4.5 \\
\hline L-9 & オンライン応答 & 風向直交方向応答 & 4.5 \\
\hline
\end{tabular}
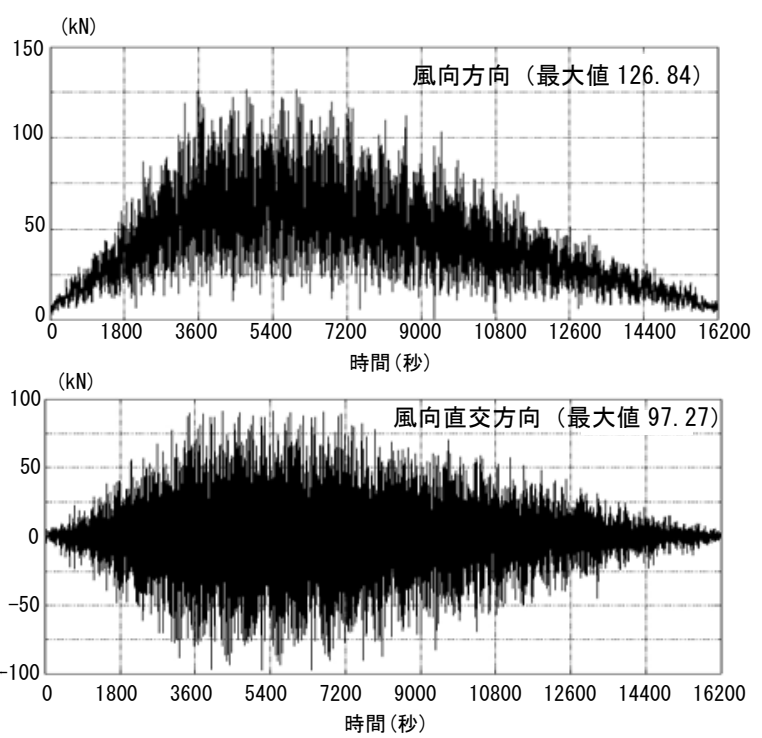

図 2 風応答波加振実験の入力波 


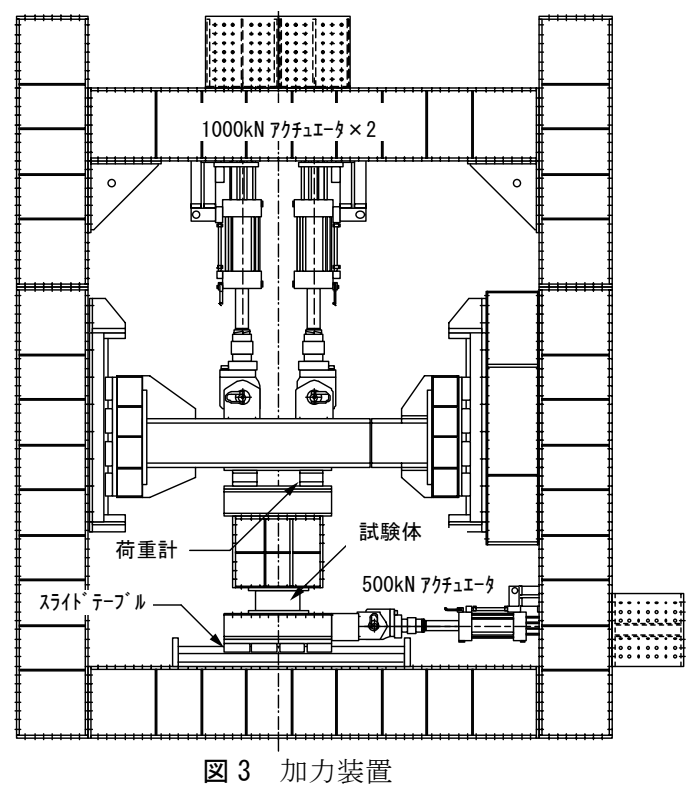

表 4 オンライン応答実験上部構造モデル諸元

\begin{tabular}{|c|c|c|c|}
\hline 質点番号 & 高さ $(\mathrm{m})$ & 重量 $(\mathrm{kN})$ & 水平剛性 $(\mathrm{kN} / \mathrm{m})$ \\
\hline 11 & 160.58 & 43841.7 & $1.064 \times 10^{6}$ \\
\hline 10 & 147.30 & 60750.5 & $8.157 \times 10^{6}$ \\
\hline 9 & 130.70 & 60750.5 & $6.532 \times 10^{6}$ \\
\hline 8 & 114.10 & 60750.5 & $7.997 \times 10^{6}$ \\
\hline 7 & 97.50 & 60750.5 & $8.740 \times 10^{6}$ \\
\hline 6 & 80.90 & 61965.8 & $1.055 \times 10^{6}$ \\
\hline 5 & 64.30 & 62776.0 & $1.028 \times 10^{6}$ \\
\hline 4 & 47.70 & 62776.0 & $8.823 \times 10^{6}$ \\
\hline 3 & 31.10 & 62776.0 & $9.626 \times 10^{6}$ \\
\hline 2 & 14.50 & 80191.2 & $3.348 \times 10^{6}$ \\
\hline 1 (免震層) & 0.00 & 34830.4 & \\
\hline \multicolumn{3}{|r}{} \\
\hline
\end{tabular}

の間には断熱板（アルミニウムカーボネート系、厚さ $12.7 \mathrm{~mm}$ 、熱 伝導率 $0.27 \mathrm{~W} /(\mathrm{m} \cdot \mathrm{K})$ ) を設置した。実験時の面圧は加力装置の性能 に基づき $9 \mathrm{MPa}$ とし、正弦波加振実験を LRB1 試験体で、風応答波 加振実験とオンライン応答実験をLRB2 試験体でそれぞれ実施した。 また、各ケースの加振前に、初期特性並びに加振実験による特性変 化を確認するため、せん断ひずみ $100 \%$ 、周期 100 秒、3 サイクルの 正弦波による基本特性試験を実施した。

計測項目は、試験体の水平荷重、鉛直荷重、水平変形および内部 温度である。荷重を 2 方向荷重計によって、変形を差動トランス型 変位計によって、温度を熱電対によってそれぞれ測定した。図 1 に 試験体の温度計測点を示す。計測点は、鉛プラグ内部 3 点 (P-1〜P-3)、 積層ゴムの高さ $1 / 2$ の部分 2 点 (RC-1、RC-2) 、同 $1 / 4$ の部分 2 点 （RQ-1、RQ-2）、フランジ部 3 点（F-1 F F-3）の合計 10 点である。

\section{3. 実験結果}

\section{1 正弦波加振実験}

図 4 に正弦波加振実験（L-1～L-5） から得られた水平荷重一水平 変形曲線を、基本特性試験の結果および LRB のゴム部のみの水平剛 性 $K_{R}(=761 \mathrm{kN} / \mathrm{m})$ と比較して示す。これより、L-2 と L-3 ではク リープ変形が生じているが、繰り返しに伴う変形量の増加は次第に 小さくなり、最終的には各履歴曲線中心位置の変形がほぼ一定值に 収束した。加振終了時の水平変形は、L-2 が $32 \mathrm{~mm} 、 \mathrm{~L}-3$ が $79 \mathrm{~mm}$ で

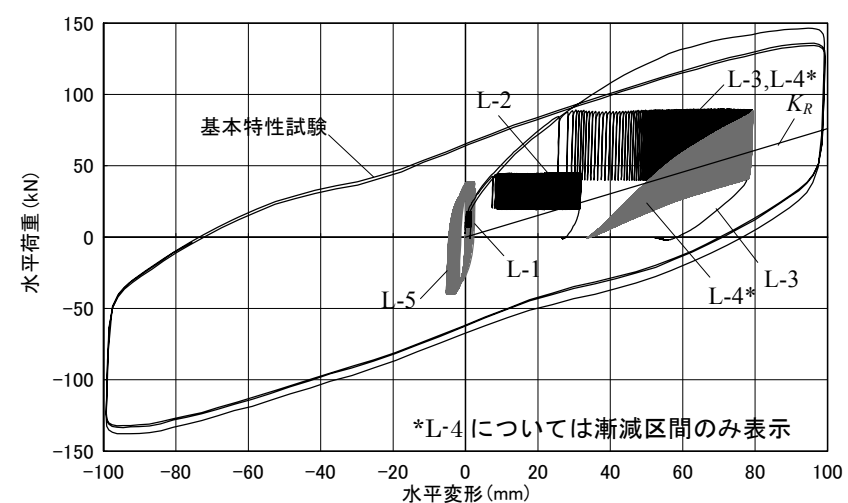

図 4 水平荷重一水平変形曲線（正弦波加振実験）

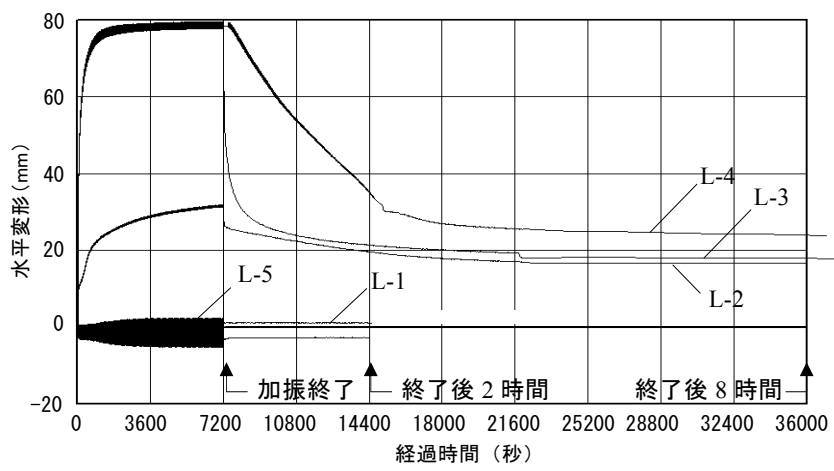

図 5 水平変形の経過時間に対する変化（正弦波加振実験）

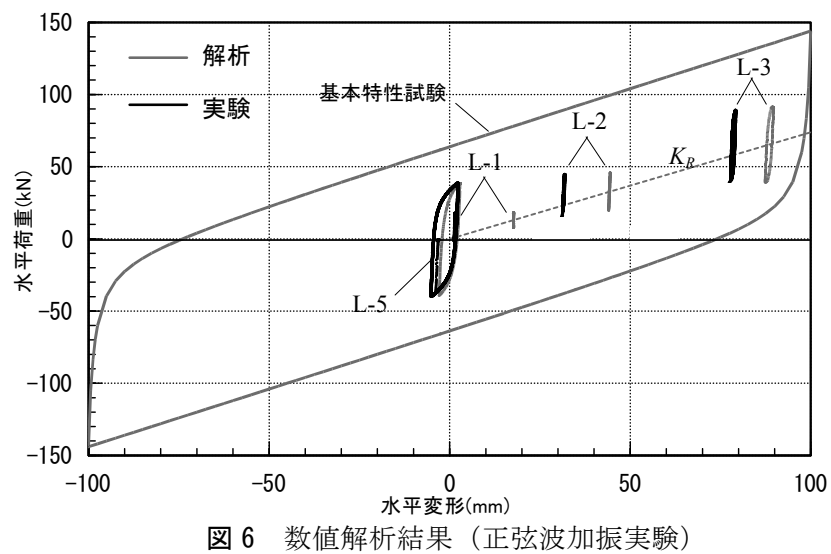

ある。L-3 では、加振終了時の変形において、入力波の平均成分 $65.4 \mathrm{kN}$ が、ゴム部のみの水平剛性 $K_{R}$ による荷重 $60.1 \mathrm{kN}(=761 \times 0.079)$ 、 に概ね対応している。これについては、繰り返し加振に伴い平均成 分に対する鉛の抵抗力が失われ、平均成分に対してゴム部の剛性の みが抵抗している状態にほぼ収束したと考えられる。一方、L-1 と L-2 では、水平変形がゴム部の水平剛性に釣合う值に達していない が、これは、水平荷重が降伏荷重よりも小さいため、平均成分に対 する鉛の抵抗力が残存しているためと考えられる。L-4 は L-3 と同 様の加振を行なった後に漸減加振を実施したケースである。漸減加 振開始後、しばらくは履歴曲線の中心点が $K_{R}$ 上に位置し、平均成分 とゴム剛性が釣り合っているが、次第に中心点が $K_{R}$ の下方に移動し、 漸減加振終了時には $34 \mathrm{~mm}$ の残留変形が生じた。 L-5 は変動成分の みによる両振幅の加振を行なったケースである。履歴曲線は原点を 中心とした対称的な曲線を描いている。加振に伴い正負ともに水平 変形が大きくなり、履歴曲線は僅かに大きくなったが、変形量は小 
さく、実験終了時の水平変形は-5 $\mathrm{mm}$ および $3 \mathrm{~mm}$ 程度である。本ケ 一スの変動成分の振幅レベルは L-3 のそれよりも大きいが、両振幅 加振としたためクリープ的な挙動が生じなかったと考えられる。

図 5 に正弦波加振実験における水平変形の経過時間に対する変化 を示す。L-2〜L-4については、加振終了後 2 時間の計測で残留変形 が収束していないと判断されたため、さらに、終了後 8 時間までの 計測を行なった。これより、L-2 と L-3 では、加振終了後に荷重を ゼロとすることにより、水平変形はそれぞれ $32 \mathrm{~mm}$ から $27 \mathrm{~mm}$ まで、 $79 \mathrm{~mm}$ から $55 \mathrm{~mm}$ まで急激に低下した。その後も変形は小さくなっ たが、減少の割合は緩やかであり、加振終了後 2 時間ではそれぞれ $20 \mathrm{~mm}$ と $22 \mathrm{~mm}$ に、加振終了後 8 時間でそれぞれ $16 \mathrm{~mm}$ と $18 \mathrm{~mm}$ に なりほぼ一定值に収束した。加振終了後に漸減加振を実施した L-4 では、荷重をゼロとした L-3 と比べて減少の割合が緩やかであり、2 時間の漸減加振終了時の水平変形は $34 \mathrm{~mm}$ と L-3 よりも大きい。し かし、漸減加振終了後 6 時間では変形が $24 \mathrm{~mm}$ となり、L-3 と同程 度の值となった。一方、L-1 と L-5 については加振終了時の水平変 形が小さく、終了後の水平変形に変化はほとんど認められなかった。

図 6 に実験結果の数值解析結果を示す。実験については実験終了 直前の履歴曲線を、解析については、LRB の小振幅域での特性を考 慮した復元力特性 ${ }^{7)}$ を用いて、簡易評価法 ${ }^{3)}$ の考え方に基づき、平 均成分の荷重がゴム部分のみの剛性による荷重に釣り合う水平変形 での履歴曲線を示している。これより、解析によって実験の荷重振 幅が精度よく表現されていること、また、実験では平均成分とゴム 剛性が釣り合う変形に達していないため、解析の水平変形が実験を 上回っており、解析が安全側の評価を与えることが分かる。

\section{2 風応答波加振実験}

図 7 に風応答波加振実験（L-6、L-7） から得られた水平荷重一水 平変形曲線を、基本特性試験の結果および $K_{R}$ と比較して示す。また、 図 8 に、風応答波加振実験における水平変形の経過時間に対寸る変 化を示す。これより、以下のことが分かる。

L-6 は風向方向応答の加振を実施したケースである。水平変形が

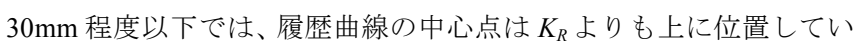
る。これは、水平荷重が降伏荷重以下であるためと考えられる。一 方、水平変形が $40 \mathrm{~mm}$ 以上では、水平荷重が降伏荷重を超えて、履 歴曲線が基本特性試験のそれに近づくとともに、その中心点が $K_{R}$ に接近している。最大変形は $87 \mathrm{~mm}$ で、履歴曲線の中心点は、 $K_{R} に$ よる同変形時の荷重 $66.2 \mathrm{kN}(=761 \times 0.087)$ と概放一致している。図 8 より、加振開始後から約 3600 秒にかけて水平変形が増大し、荷重 最大值 $118.6 \mathrm{kN}$ (計測值) を含む大きな荷重振幅が連続する 3600〜 6600 秒の区間（風速最大域と寸る）において、水平変形は $80 \mathrm{~mm}$ 前 後の值を保持し最大值 $87 \mathrm{~mm}$ を記録した。その後、荷重振幅が小さ くなるにつれて緩やかに水平変形は小さくなり、加振終了時には $33 \mathrm{~mm}$ の残留変形が生じた。この変形は、正弦波加振実験 L-4 の漸 減加振終了時の残留変形とほぼ同程度である。なお、ここでは示し ていないが、本ケースでも加振終了後に引き続き 6 時間の計測を実 施しており、その結果によれば、残留変形は $18 \mathrm{~mm}$ にほぼ収束した。

風向直交方向応答の加振を実施した L-7 では、クリープ的な挙動 は認められず、荷重最大值 $76.9 \mathrm{kN}$ （計測值）を含む大きな荷重振幅 が継続する風速最大域において、水平変形は最大となり、その值は $22 \mathrm{~mm}$ 程度である。履歴曲線の包絡線は原点を中心とした対称的な

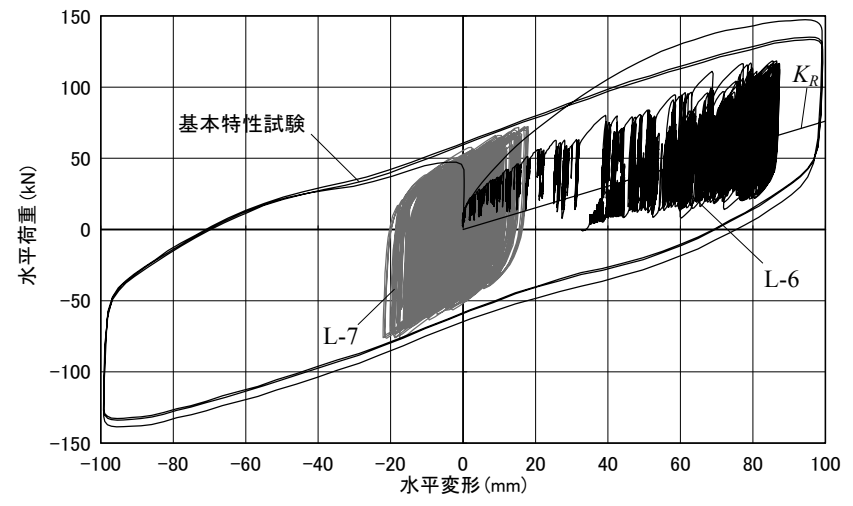

図 7 水平荷重一水平変形曲線（風応答波加振実験）

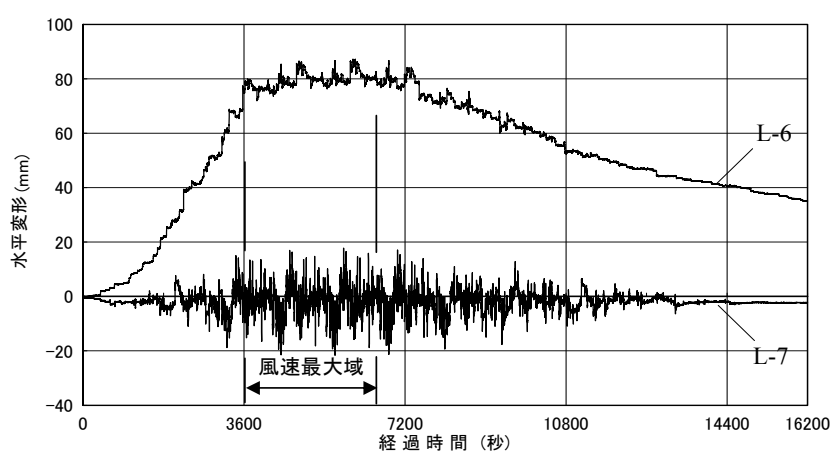

図 8 水平変形の経過時間に対する変化（風応答波加振実験）

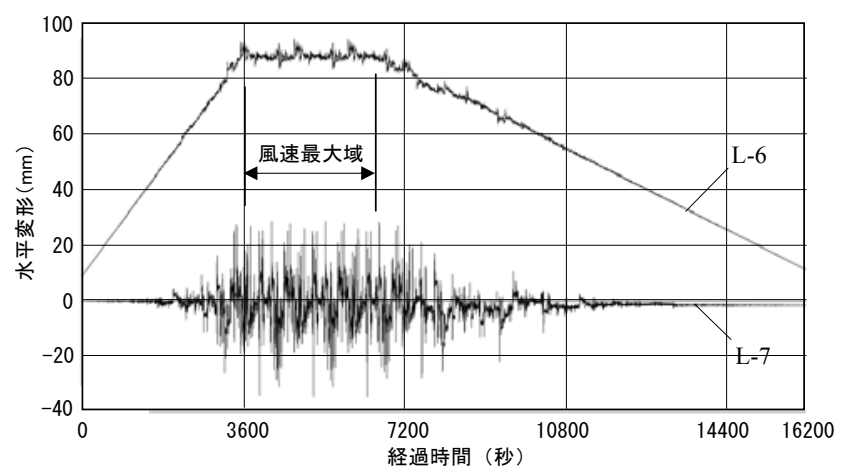

図 9 モデル免震建物の解析結果

曲線となっている。

図 9 に、2.2 項で示したモデル免震建物の風応答解析から得られ た免震層水平変形の経過時間に対寸る変化を示す。これより、図 8 と比較すると、解析によって強風を受ける LRB の変形挙動を概ね表 現し得ることが分かる。L-6 については、風速最大域において解析 の水平変形が実験よりも大きく、解析が安全側の評価となっている が、これは、図 7 に示寸ように、実験の水平変形が履歴曲線の中心 点とゴム剛性が釣り合う変形に達していないことによる。

実験時に計測された水平荷重の最大值は、図 2 に示した入力波の 最大值（L-6：126.84kN、L-7：97.27kN）に対して約 94\%および約 80\%程度となっている。L-7 では実験における再現性が小さくなっ ているが、これは、L-7 では L-6 よりも荷重と変形の振幅が大きく、 アクチュエータの荷重制御が精度よく行なえなかったためである。

\section{3 温度の変化}

図 10 に、正弦波加振実験 L-5 と風応答波加振実験 L-7 における試 験体内部の温度の変化を示す。これより、以下のことが分かる。

L-5 では、加振に伴い各計測点の温度が上昇しており、特に鉛プ 
ラグ内部の P2 と P3 の温度上昇が大きく、初期温度 $19^{\circ} \mathrm{C} か ~ 28^{\circ} \mathrm{C}$ まで $9^{\circ} \mathrm{C}$ 程度上昇した。また、鉛プラグに近い積層ゴム部の $\mathrm{RQ} 1$ と $\mathrm{RC} 1$ でも大きく、 $20^{\circ} \mathrm{C}$ から $25^{\circ} \mathrm{C}$ まで $5^{\circ} \mathrm{C}$ 程度上昇している。一方、 鈶プラグから離れたフランジ部 MT3、ゴム最外縁 RQ2 と RC2 では 温度上昇が $2^{\circ} \mathrm{C}$ 程度と小さい。

L-7 では、加振に伴い各計測点の温度が上昇し、大きな荷重振幅 が継続する 3600〜 7200 秒の区間において、鉛内部の温度 P1 が $3{ }^{\circ} \mathrm{C}$ 程度上昇し $21^{\circ} \mathrm{C}$ で最大となり、同じく $\mathrm{P} 2$ と $\mathrm{P} 3$ がそれぞれ $5^{\circ} \mathrm{C}$ 上昇 し $24^{\circ} \mathrm{C}$ で最大となっている。その後、荷重振幅が小さくなるに従い 温度は低下し、加振終了時には P1 が $19^{\circ} \mathrm{C} 、 \mathrm{P} 2$ と P3 の温度は $20^{\circ} \mathrm{C}$ となった。ゴム内部の温度変化は小さく最大でも $2^{\circ} \mathrm{C}$ 程度である。

なお、L-3 と L-6 では大きなクリープ変形が生じているが、加振 による温度上昇はほとんど認められなかった。これは、図 4 や図 7 の履歴曲線からも分かるように、平均成分による変形が大きくなっ ても変動成分による振幅が小さいためである。

L-5、L-7 について、実験終了時における累積履歴吸収エネルギー を履歴曲線より計算すると、それぞれ $757 \mathrm{kN} \cdot \mathrm{m}$ および $346 \mathrm{kN} \cdot \mathrm{m}$ と 求められる。この履歴エネルギーが断熱状態における鉛の温度上昇 に全て使われたと仮定すると、鉛の体積を $1330 \mathrm{~cm}^{3}$ 、鉛の比熱を $0.129 \mathrm{~J} / \mathrm{g}^{\circ} \mathrm{C}$ 、鉛の密度を $11.34 \mathrm{~g} / \mathrm{cm}^{3}$ とすれば、温度上昇值はそれぞ れ $389^{\circ} \mathrm{C} 、 178^{\circ} \mathrm{C}$ と算定される。一方、実験による鉛プラグの温度上 昇はそれぞれ $9^{\circ} \mathrm{C}$ 程度と $5^{\circ} \mathrm{C}$ 程度と小さい。これは、加振振幅が小さ く単位時間当たりに鉛プラグで発生する熱量が微少であり、また、 長時間加振のため、鉛プラグから周囲に逃げる熱エネルギー量が大 きいためと考えられる。すなわち、風荷重による温度上昇は小さく 積層ゴム特性にほとんど影響を与えないことが分かる。一方、実大 積層ゴムでは、スケールの影響により温度上昇はさらに大きいと考 えられるが ${ }^{8)}$ 、本実験の温度上昇が $10^{\circ} \mathrm{C}$ 以下と小さいことを考慮す れば、風荷重が実大ゴムの特性に及ぼす影響は小さいと推察される。

\section{4 オンライン応答実験}

オンライン応答実験の精度を確認するため、実験時の解析から求 められた水平変形（計算值）と変位計によって実際に計測された水 平変形（計測值）を比較した。これより、計測值は計算值よりも小
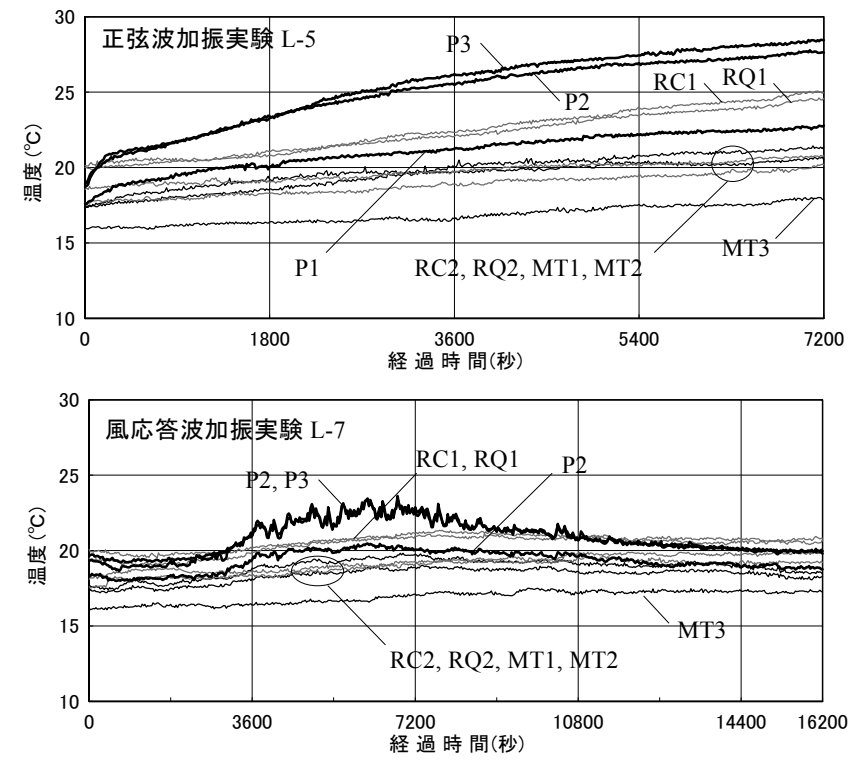

図 10 試験体の温度変化
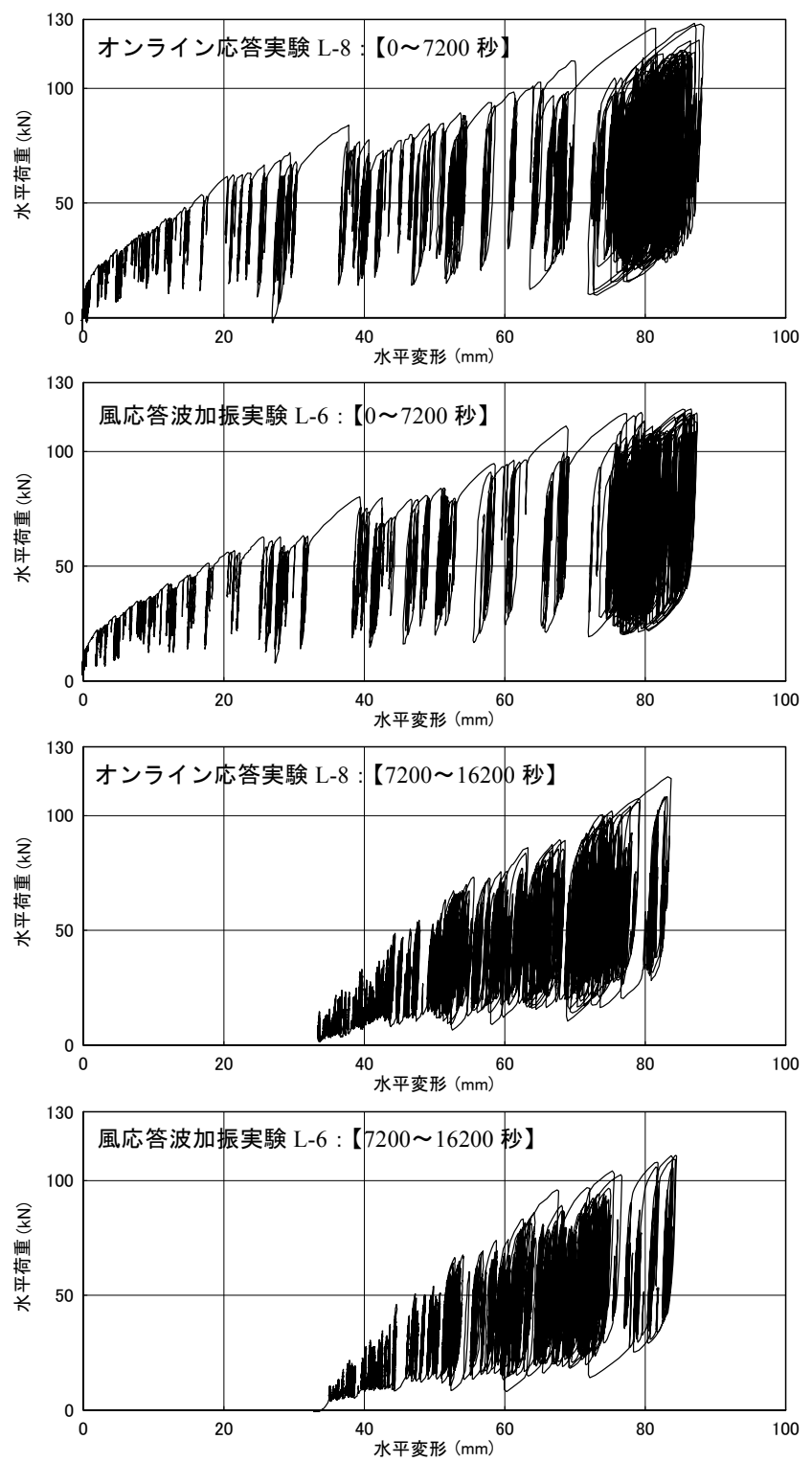

図 11 オンライン応答実験と風応答波加振実験の比較（風向方向）
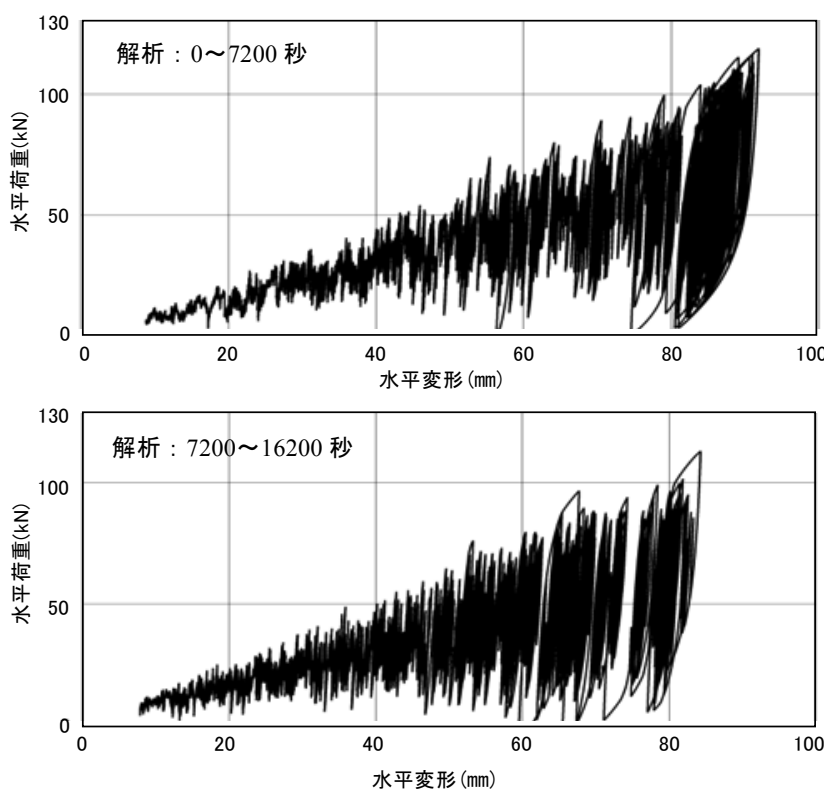

図 12 解析による水平荷重一水平変形（風向方向） 


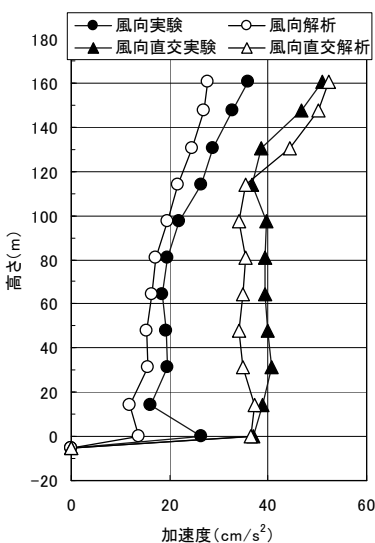

図 13 上部構造応答の比較

さくなる傾向が見られたが、その差は最大でも、風向方向 L-8 で $3 \%$ 程度、風向直交方向 L-9 で 7 8\%程度であり、リアルタイムでのオ ンライン応答実験が精度よく制御されていたことを確認した。

図 11 に、オンライン応答実験から得られた結果のうち、風向方向 L-8 の水平荷重一水平変形曲線を風応答波加振実験 L-6 の結果と比 較して示す。図は変形が増加する区間（0７200 秒）と減少する区 間（7200〜16200 秒）に分けて示した。これより、両区間において オンライン応答実験と風応答波加振実験の曲線は良く一致している。

実験で用いた上部構造モデルを対象とした風応答解析を別途実施 し、オンライン応答実験の結果と比較した。解析における LRB の評 価法は、前述したモデル免震建物で用いたものと同一の簡易評価法 である。図 12 に、解析から得られた LRB の水平荷重一水平変形曲 線を示す。簡易評価法による解析では残留変形を考慮できないため、 変形が減少する区間においても増加する区間と同様の履歴曲線を描 き、最終的には水平変形がゼロに近づいている。しかし、変形が増 加する区間においてクリープ変形と荷重振幅が増大寸る挙動が表現 されており、解析と実験は良い対応を示している。図 13 に、上部構 造の加速度、水平変形の高さ方向の分布について、オンライン実験 と解析の結果を比較して示す。これより、上部構造の応答值につい ても実験と解析は非常によく一致している。加速度については、風 向方向実験の高さ $0 \mathrm{~m}$ (免震層) における值がやや突出しているが、 これは実験時に加力装置に生じた高次振動の影響によるものである。 以上より、オンライン応答実験が精度よく実施され、解析結果と の合致度も高いことが確認された。風外力下における建物応答特性 が実験的に示されたとともに LRB のモデル化と解析法の妥当性が 確かめられたことになる。

\section{4. まとめ}

鈶プラグ入り積層ゴム（LRB）を対象として風荷重下におけるク リープ特性や温度上昇の影響等を把握することを目的とし、長時間 加振実験を実施した。実験は、通常の設計範囲を想定した正弦波加 振実験、実際の強風を想定した風応答波加振験実験、風応答解析に 実験值を直接用いるリアルタイムオンライン応答実験の 3 種類であ る。本論から得られた知見は以下の通りである。

・実験結果より、クリープ変形や残留変形を含めた、比較的小振幅 の LRB の履歴特性が得られた。クリープ変形は加振に伴い増大寸 るが、水平荷重が降伏荷重を超えるケースでは、入力波の平均成 分がゴム部の水平剛性による荷重と概称釣り合う水平変形に収束
した。加振終了後 8 時間経過した後の残留変形は、強風が漸減す ることを想定した加振を行ったケースを含め、20mm 程度（ゴム 総厚の $20 \%$ ）に収束した。残留変形はゴム部と鉛の荷重の釣り合 いによって生じるが、残留変形の予測については、鉛のクリープ の影響を考慮する必要があると考えられ、今後の課題である。

・実験から得られた履歴特性は、小振幅特性を考慮した修正 HD モ デルを採用した簡易評価法による解析結果と概ね対応の良い結果 となった。また、解析の水平変形は実験に対して安全側の評価を 与える結果となった。

・正弦波加振実験および風応答波加振実験いずれについても、温度 上昇は小さくその影響がほとんどないことが確認された。

・オンライン応答実験における計測值と計算值はよく一致しており、 実験がリアルタイムで精度よく制御されていたことが確認された。 また、オンライン応答実験の結果は風応答波加振実験の結果と概 ね一致し、風応答解析の結果とも良い対応を示した。風外力下に おける建物応答特性が実験的に示されたとともに LRB のモデル 化と解析法の妥当性が確認された。

\section{謝辞}

本論は、国土交通省の平成 22 年度建築基準整備促進事業「12 免 震建築物の基準の整備に資する検討」9)の一環として行なったもの の一部をまとめたものである。本事業のために日本免震構造協会内 に設置された検討委員会（委員長 : 北村春幸東京理科大学教授）の 委員各位に感謝します。

\section{参考文献}

1)仲村崇仁、竹中康雄、池永雅良、鈴木雅靖、河内山修、吉川和秀 : 高層免 震建物の風応答における LRB の健全性に関する研究（その 1 ）LRB の風荷 重時刻歷加振、日本建築学会大会学術講演梗概集 B-2、pp.489-490、2003.9. 2)河内山修、竹中康雄、池永雅良、鈴木雅靖、仲村崇仁、吉川和秀、金子修 平: 高層免震建物の風応答における LRB の健全性に関する研究（その 2) 積層ゴムの一定および正弦波加力実験、日本建築学会大会学術講演梗概集 B-2、pp.491-492、2003.9.

3)竹中康雄、飯塚真巨、鈴木雅靖、吉川和秀、山田和彦 : 鉛プラグ型積層ゴ ムのクリープ性を考慮した高層免震建物の風応答簡易評価法 : 日本建築学 会構造系論文集、No.561、pp.89-94、2002.11.

4)清水建設株式会社、株式会社小堀鐸二研究所、社団法人日本免震構造協会 : 国土交通省平成 21 年度建築基準整備促進補助金事業「12 免震建築物の基 準の整備に資する検討」報告書、平成 22 年 3 月.

5)鈴木雅靖、竹中康雄、近藤明洋、飯場正紀、大熊武司、松井正宏 : 高層免 震建築物の風応答時刻歷解析による検討 (その 1 対象免震建物と風力波 形評価)、日本建築学会大会学術講演梗概集 B-2、pp.277-278、2010.9.

6)近藤明洋、竹中康雄、鈴木雅靖、飯場正紀、安井八紀、吉江慶祐 : 高層免 震建築物の風応答時刻歴解析による検討（その 2 風応答解析結果とその 分析)、日本建築学会大会学術講演梗概集 B-2、pp.279-280、2010.9.

7)竹中康雄、山田和彦、吉川和秀 : 免震用積層ゴム支承の曲線型復元力モデ ル:「修正 HD モデル」、日本建築学会技術報告集、第 14 号、pp.87-92、2001.12. 8)竹中康雄、近藤明洋、高岡栄治、引田真規子、北村春幸、仲村崇仁 : 積層 ゴムの熱・力学的連成挙動に関する実験的研究、日本建築学会構造系論文 集、第 74 巻、第 646 号、pp.2245-2253、2009.12.

9)鹿島建設株式会社、株式会社織本構造設計、株式会社松田平田設計：国土 交通省平成 22 年度建築基準整備促進事業「12 免震建築物の基準の整備に 資する検討」報告書、平成 23 年 3 月.

[2011年 6 月 17 日原稿受理 2011 年 8 月 9 日採用決定］ 